\title{
Emotional Intelligence and Job Satisfaction among Bank Managers with Special Reference to Malappuram District, Kerala
}

\author{
J. Aravind $^{1}$ and P. N. Priyalakshmi ${ }^{2}$ \\ ${ }^{1 \& 2}$ Assistant Professor of Commerce, N.S.S College, Malappuram, Kerala, India \\ E-Mail: aravindjayanthy@gmail.com, priyaaravind4u@gmail.com
}

\begin{abstract}
Emotions play a vital role in ordering human experiences. Emotional Intelligence is the capacity to recognize our own feelings and those of others for motivating ourselves and for managing emotions well in ourselves and in our relationship. Emotional Intelligence focuses on the softer skills of building and maintains human relationships. This aspect of life assumes a lot of importance since a person is not detached from the human element, be it work place, the home front or the social circle, human interactions are inevitable and our success depends to a large extent on what we make of these interactions and relationships. Job Satisfaction is the combination of psychological, physiological and environmental circumstances that cause a person truthfully to say I am satisfied with my job. The study is intended to analyze Emotional Intelligence of bank managers and their Satisfaction towards their job. It also helps to identify and analyze the Dimensions of Emotional Intelligence and various factors which influence Emotional Intelligence and Job Satisfaction.
\end{abstract}

Keywords: Emotional Intelligence, Job Satisfaction, Dimensions

\section{INTRODUCTION}

Emotional Intelligence is a type of social intelligence that enables to control one's own and others emotions, make a choice between them and the ability to use these emotions to set his life. Emotional Intelligence involves the ability to monitor one's own and others' feelings and emotions, to discriminate among them and to use this information to guide one's thinking and actions.” (Salovey \& Mayer, 1990). Emotional Intelligence is regarded as a set of behaviours, viewed as humans' ability to process emotions and deal effectively with them. It is about understanding how people behave with the presence of emotions and emotionally charged thoughts. It is a master of aptitude. a capacity that profoundly affect other abilities,either facilitating or intefering with them (Goleman D., 1996).

\section{SIGNIFICANCE OF THE STUDY}

An important factor in our ability to successfully connect is emotional intelligence. When it comes to happiness and success in our relationships, career and personal goals, emotional intelligence (EQ) matters just as much as the more well known, intellectual ability (IQ). We need emotional intelligence to turn intention in to action, in order to make informed decision about the thing that matter most to us, and to connect to others in productive and nurturing ways. The study on emotional intelligence and job satisfaction is thus significant in the current scenario of banking sector as it is one of the fastest growing sector in the country. The study helps to identify the various factors which affect the emotional intelligence and job satisfaction among bank managers.

\section{REVIEW OF LITERATURE}

Anurag Pahuja and Anu Sahi (2012) in the study "Emotional Intelligence (EI) among Bank Employees: An Empirical Study" found that as far as empathetic attitude is concerned, females are more empathetic than males. The statistical score of females (Mean 3.985, S.D 0.574) as compared to men (Mean 3.743, S.D 0.562) makes it clear. Thus it can be said that females are more considerate than males under study.

Vinoth Vijay and Mary Ezhilarasi (2013) in the study "A Study on Emotional Intelligence among Bank Employees in Vellore District" found that Majority (42\%) of the respondents are clear about their goals and their future among the motivational factors. Just $4 \%$ of the respondents find it hard to maintain their enthusiasm when they encounter setbacks. Employees are clear about their goals for the future stands first among respondents view on Motivation Factors.

Vibhor Jain and Sonia Gupta (2014) in the Study "The Impact of Emotional Intelligence on Service Quality in Indian Private Banks: with Special Reference to Moradabad City" found that he comparison between average of mean scores of different private sector bank employees is highest in the case of HDFC Bank (4.25) and lowest in the case of NAINITAL Bank (4.01). This shows that the employees of HDFC Bank are more self-Aware in comparison with the employees of other banks.

Samuel Thavaraj (2012) in the study "A Study on Identifying the Level of Emotional Intelligence among Bank Managers in Madurai District, South India” found that the most important determinant of emotional intelligence is self-motivation since its eigen value and the per cent of variation explained are 3.2197 and 22.98 per cent respectively. The second important determinant of emotional intelligence is social skills. 


\section{OBJECTIVES OF THE STUDY}

The following are the objectives of the study

1. To study the level of emotional intelligence among bank managers.

2. To identify and analyze the dimensions of emotional intelligence among bank managers.

3. To identify the factors influencing emotional intelligence of bank managers.

4. To know the various reaction levels of bank managers under critical situations.

5. To measure the overall level of job satisfaction of bank managers.

\section{HYPOTHESES OF THE STUDY}

The following are the hypotheses framed for the study

1. There is no association between category of bank and level of job satisfaction of bank managers.

2. There is no significant difference between the mean ranks of the opinion of bank managers as regards factors influencing emotional intelligence.

3. There is no significant difference between the mean ranks of the opinion of bank managers as regards factors influencing job satisfaction.

4. There is no significant difference between the mean scores of public sector and private sector bank managers with regards to emotional intelligence of bank managers.

5. There is no significant difference between the mean scores of designations of bank managers with regards to emotional intelligence of bank managers.

6. There is no significant difference between the mean scores of age of bank managers with regards to emotional intelligence of bank managers.

\section{METHODOLOGY}

The population of the study constitutes the bank managers of public sector and private sector banks in Malappuram District. The sample size is fixed as 100 , out of which 50 managers from public sector banks and 50 from private sector banks are selected. Purposive sampling method is used for selecting bank managers. Both primary and secondary data are used for the study.

The primary data are collected from bank managers in Malappuram District and secondary data are collected from books, journals, and internet. Questionnaire method is used for collecting primary data. The tools of analysis include Percentage, Ranking, Scaling, Chi-Square test, Friedman's test, Mann Whitney U test and Kruskal Wallies test.
The concept 'Emotional Intelligence' is analyzed by using 24 statements. The attitude towards banking job is analyzed by using 14 statements. All the statements are measured by using a three point scale (Agree, Undecided, Disagree).

\section{RESULTS AND DISCUSSION}

TABLE I DIMENSIONS OF EMOTIONAL INTELLIGENCE

\begin{tabular}{|l|c|c|}
\hline \multicolumn{1}{|c|}{ Dimensions } & Mean & Std Dev \\
\hline Self Awareness & 2.74 & 0.485 \\
\hline Self Regulation & 2.50 & 0.701 \\
\hline Motivation & 2.74 & 0.514 \\
\hline Empathy & 2.56 & 0.653 \\
\hline Social Skills & 2.82 & 0.422 \\
\hline
\end{tabular}

The mean values of all the components are very high, which indicates that the bank managers have a very high level of emotional intelligence. The most important dimension of emotional intelligence was Social Skill (2.82) and the least important was Self-Regulation (2.50).

TABLE II FACTORS INFLUENCING EMOTIONAL INTELLIGENCE

\begin{tabular}{|l|c|c|}
\hline \multicolumn{1}{|c|}{ Components } & Mean & Rank \\
\hline Communication Skills & 4.62 & 2 \\
\hline Assertiveness & 2.09 & 6 \\
\hline Problem Solving Capacity & 4.78 & 1 \\
\hline Social Interactions & 4.03 & 3 \\
\hline Optimism & 3.03 & 4 \\
\hline Empathy & 2.47 & 5 \\
\hline
\end{tabular}

The most important factor which influenced the emotional intelligence of bank managers was Problem Solving Capacity (4.78) and the least influenced was Assertiveness (2.09).

TABLE III REACTIONS UndeR CRITICAL SituATIONS

\begin{tabular}{|l|c|}
\hline \multicolumn{1}{|c|}{ Components } & Frequency \\
\hline Reacts Aggressively & 6 \\
\hline Demands Grace Time & 5 \\
\hline Try to Make Excuses & 5 \\
\hline Use Intelligence & 84 \\
\hline Total & 100 \\
\hline
\end{tabular}

Only $6 \%$ of the bank managers opined that they react aggressively under critical situations, $5 \%$ demands grace time, $5 \%$ bank managers try to make excuses and $84 \%$ of the bank managers use their intelligence for facing critical situations. 
TABLE V Results of Hypotheses Testing

\begin{tabular}{|l|c|c|c|}
\hline \multicolumn{1}{|c|}{ Hypotheses } & Test & P Value & Result \\
\hline $\begin{array}{l}\text { There is no association between category of banks and } \\
\text { level of job satisfaction of bank managers }\end{array}$ & Chi-Square & 0.196 & Ho Accepted at 5\% \\
\hline $\begin{array}{l}\text { There is no significant difference between the mean ranks } \\
\text { of the opinion of the bank managers as regards the factors } \\
\text { influencing emotional intelligence }\end{array}$ & Friedman's Test & $<0.000$ & Ho Rejected at $1 \%$ \\
\hline $\begin{array}{l}\text { There is no significant difference between the mean ranks } \\
\text { of the opinion of the bank managers as regards the factors } \\
\text { influencing job satisfaction }\end{array}$ & Friedman's Test & $<0.000$ & Ho Rejected at $1 \%$ \\
\hline $\begin{array}{l}\text { There is no significant difference between the mean scores } \\
\text { of public sector and private sector bank managers with } \\
\text { regards to emotional intelligence of bank managers }\end{array}$ & $\begin{array}{c}\text { Mann Whitney U } \\
\text { Test }\end{array}$ & 0.777 & Ho Accepted at $5 \%$ \\
\hline $\begin{array}{l}\text { There is no significant difference between the mean scores } \\
\text { of designations of bank managers with regards to } \\
\text { emotional intelligence of bank managers }\end{array}$ & $\begin{array}{c}\text { Kruskal } \\
\text { Wallies Test }\end{array}$ & 0.036 & Ho Rejected at $5 \%$ \\
\hline $\begin{array}{l}\text { There is no significant difference between the mean scores } \\
\text { of age of bank managers with regards to emotional } \\
\text { intelligence of bank managers. }\end{array}$ & $\begin{array}{c}\text { Kruskal } \\
\text { Wallies Test }\end{array}$ & 0.562 & Ho Accepted at 5\% \\
\hline
\end{tabular}

\section{CONCLUSION}

Emotional Intelligence is considered as a key factor in creating and maintaining effective relationship in the work place. The study revealed that bank managers in Malappuram District have high level of emotional intelligence and social skill is the most important component of emotional intelligence among bank managers. The factors such as communication skills, assertiveness, Problem solving capacity, social interaction, optimism and empathy influence the emotional intelligence of bank managers. The managers use their intelligence while facing critical situations. The analysis of overall satisfaction level revealed that $81 \%$ bank managers were satisfied with their banking job.

\section{REFERENCES}

[1] Samuel Thavaraj. (2012, October). A Study on identifying the level of Emotional Intelligence among Bank Managers in Madurai District. Research World - Journal for Arts, Science and Commerce, 3(4), 5866.

[2] Spyros Papathanasiou and Maria Siati. (2014), Emotional Intelligence and Job Satisfaction in Greek Banking Sector. Research in Applied Economics, 6(1), 225-239.

[3] Swarnalatha, V and Sekar, S., (2016, December). The Impact of Experience on Emotional Intelligence among Private Bank Managers in Bangalore City, Research Journal of Management Sciences, 5(12), 7-9.

[4] Uma Devi, A and Chitti Babu, P. (2015), August. A Study on Emotional Intelligence among Faculty Members of Selected Engineering Colleges in Kadapa Region, International Journal of Current Research and Academic Review, 3(8) 256-261.

[5] Arvind Hans. (2013, July). Emotional Intelligence among Teachers: A Case Study of Private Educational Institutions in Muscat, International Journal of Application or Innovation in Engineering \& Management, 2(7), 359-366. 